\title{
Outer-membrane protein- and rough lipopolysaccharide- specific monoclonal antibodies protect mice against Brucella ovis
}

\author{
R. A. BOWDEN*, A. CLOECKAERT, M. S. ZYGMUNT and G. DUBRAY†
}

Laboratoire de Pathologie Infectieuse et Immunologie, Institut National de la Recherche Agronomique, Centre de Recherches de Tours, 37380 Nouzilly, France

\begin{abstract}
Summary. Brucella ovis, a naturally virulent rough Brucella species, is the aetiological agent of ram epididymitis. The identification of protective antigens is necessary to obtain a safe, specific subcellular vaccine. Monoclonal antibodies (MAbs) directed at both brucella outermembrane proteins (OMPs) and rough lipopolysaccharide (R-LPS) in a mouse protection test were used to identify potential targets for humoral immunity. Mixtures of MAbs directed at the 16-5-, 25-27-, 31-34- and 36-38-kDa OMPs conferred significant protection 7 days after challenge with reference strain $B$. ovis $63 / 290$ compared with controls receiving either saline or an anti-brucella O-polysaccharide MAb. Furthermore, an anti-R-LPS MAb tested alone conferred protection at a level comparable with that obtained with the mixture of antiOMP MAbs. The combination of protective OMP MAbs with the anti-R-LPS MAb was also strongly protective. One combination of OMP MAbs, which bound intensely to $B$. ovis in vitro, was ineffective. These results indicate that $B$. ovis OMPs and R-LPS are targets for protective antibodies and that they can be regarded as candidates for ram epididymitis subcellular vaccines.
\end{abstract}

\section{Introduction}

Brucella ovis is the aetiological agent of ram epididymitis. ${ }^{12}$ This condition causes infertility in males and may result in abortion and stillbirths in ewes and weak newborn lambs. Thus, $B$. ovis infections are of economic concern in sheep breeding. Control measures include elimination of rams found positive in serological tests and vaccination when prevalence is high. Although no B. ovis vaccines have been marketed so far, $B$. melitensis Revl vaccine, currently used to control ovine and goat brucellosis caused by $B$. melitensis, has been shown also to confer protection against $B$. oris. ${ }^{3}$ Nevertheless, in those areas in which $B$. melitensis is not present, the use of the Rev 1 vaccine can complicate serology ${ }^{1}$ mainly because of the induction of antibodies to O-polysaccharide (OPS) of smooth strains.

The outer membrane of $B$. ovis has been studied by several groups searching for antigens useful for diag-

Received 7 April 1995: accepted 25 April 1995.

*Present address: Laboratorio de Inmunoquímica y Biotecnologia, Facultad de Ciencias Veterinarias. UNICEN, Pinto 339 (7000) Tandil. Argentina.

+Correspondence should be sent to Dr G. Dubray. nosis $^{4-10}$ and for protection. ${ }^{11,12}$ A hot-saline extract (HS) from $B$. ovis ${ }^{1,6}$ has been found to protect mice and rams in experimental conditions. This preparation contains outer-membrane proteins (OMPs) and the rough lipopolysaccharide (R-LPS) ${ }^{8,13}$ The former are involved in the protective activity observed. ${ }^{11,12}$ It has also been reported that HS-induced protection is mainly antibody-mediated. ${ }^{12}$ However, the immunological identity of the antigens involved in protection against $B$. ovis remains to be elucidated.

This study provides preliminary evidence of the protective activity of monoclonal antibodies (MAbs) specific for both brucella OMP and R-LPS epitopes against $B$. ovis in mice.

\section{Materials and methods}

\section{Bacteria and cultures}

The reference strain $B$. ovis $63 / 290$, from the INRA Nouzilly Brucella culture collection, was grown for 24 h on Tryptose-soy Agar (Difco) supplemented with horse serum $5 \%$ in an atmosphere with $\mathrm{CO}_{2} 10 \%$ as recommended. ${ }^{14}$ 
Table. Binding of OMP- and R-LPS-specific MAbs on to B. ovis cell surface

\begin{tabular}{|c|c|c|c|c|}
\hline \multirow[b]{2}{*}{$\begin{array}{l}\text { MAb } \\
\text { denomination }\end{array}$} & \multirow[b]{2}{*}{$\begin{array}{l}\text { Specificity* } \\
\text { (OMP kDa) }\end{array}$} & \multirow[b]{2}{*}{$\begin{array}{c}\text { Ig } \\
\text { Isotype }\end{array}$} & \multicolumn{2}{|c|}{ ELISA } \\
\hline & & & $\begin{array}{c}\text { Max } \\
\text { absorbance }\end{array}$ & $\begin{array}{l}\log \\
\text { titret }\end{array}$ \\
\hline $\mathrm{A} 76 / 08 \mathrm{C} 03 / \mathrm{G} 03$ (a) $\dagger$ & $16 \cdot 5$ & G2a & 1.79 & $5 \cdot 77$ \\
\hline $\mathrm{A} 68 / 29 \mathrm{E} 03 / \mathrm{C} 10\left(\mathrm{a}^{\prime}\right)$ & $16 \cdot 5$ & G2a & $0 \cdot 82$ & $2 \cdot 43$ \\
\hline A59/01E11/D11 (b) & $25-27$ & G2a & 0.65 & 1.95 \\
\hline $\mathrm{A} 59 / 05 \mathrm{~F} 01 / \mathrm{C} 09\left(\mathrm{~b}^{\prime}\right)$ & $25-27$ & G2a & $2 \cdot 16$ & $5 \cdot 29$ \\
\hline $\mathrm{A} 59 / 10 \mathrm{~F} 09 / \mathrm{G} 10$ (c) & $31-34$ & G2a & $2 \cdot 10$ & $5 \cdot 77$ \\
\hline $\mathrm{A} 68 / 15 \mathrm{~B} 06 / \mathrm{C} 08(\mathrm{~d})$ & $36-38$ & G2a & $2 \cdot 34$ & $3 \cdot 39$ \\
\hline $\mathrm{A} 63 / 04 \mathrm{D} 11 / \mathrm{G} 01\left(\mathrm{~d}^{\prime}\right)$ & $36-38$ & G2a & $1 \cdot 08$ & $2 \cdot 43$ \\
\hline $\mathrm{A} 68 / 03 \mathrm{~F} 03 / \mathrm{D} 05$ (e) & R-LPS & $\mathrm{G} 2 \mathrm{~b}$ & 3.00 & $5 \cdot 77$ \\
\hline 04/F09 (f) & OPS & G2a & $0 \cdot 70$ & 1.95 \\
\hline
\end{tabular}

ELISA values were obtained by testing individual MAbs against whole-cell B. ovis $63 / 290$.

* Denomination of OMPs are given after their apparent molecular mass, i.e. 16.5 being OMP of $16.5 \mathrm{kDa}$. OPS, O-polysaccharide moiety of smooth lipopolysaccharide; R-LPS, rough lipopolysaccharide.

$\dagger$ Single letter denominations were used to simplify description of $\mathrm{MAb}$ mixtures in the figure.

$\ddagger$ Titre was established as the last MAb dilution giving an $E$ $(414 \mathrm{~nm}) \geqslant$ twice as high as the blanks.

\section{Monoclonal antibodies}

The MAbs used were as described previously. ${ }^{15-21}$ Their denominations and characteristics are given in the table. For ELISA determinations, the cells were washed in sterile phosphate-buffered saline, $\mathrm{pH} 7 \cdot 4$, heat-inactivated $\left(65^{\circ} \mathrm{C}, 60 \mathrm{~min}\right)$ and cooled, and adjusted to an optical density of 1.0 . This suspension was distributed (100 $\mu \mathrm{l} /$ well $)$ in 96-well flat-bottomed microtitration plates and the assay was conducted in the conditions described previously. ${ }^{15,16}$ Titres were determined by interpolating in the slope at an absorbance value twice as high as the blanks.

\section{Mouse protection test}

Protection conferred by MAbs to mice was screened as described previously ${ }^{16}$ with some modifications. Briefly, MAbs were prepared, individually or in mixtures, in five-fold dilutions of ascitic fluid in PBS and then filter-sterilised. Female BALB/c mice (6-7 weeks-old, four mice/group) were inoculated subcutaneously ( $0 \cdot 1 \mathrm{ml}$ of each MAb dilution) the day before infection with $2 \times 10^{6}$ cfu of $B$. ovis $63 / 290$. Mice were killed 7 days after challenge for individual spleen counts, which were expressed in mean log cfu (SD)/group. The experiment included two control groups, one inoculated with saline, and the other with anti-OPS MAb (MAb 04F09), OPS being absent from $B$. ovis. Statistical significance of differences was determined after variance analysis by comparison of group means to the negative control mean by Dunnett's procedure, with the InStat ${ }^{\circledR}$ (Abacus, Cal) software.

\section{Results}

Binding of MAbs on to B. ovis $63 / 290$ as determined by ELISA is shown in the table. For each OMP (except for the 31-34-kDa OMP) the two MAbs tested showed different binding activity in terms of both maximal absorbance value and titre. Thus, the order of binding activity in ELISA was A76/08C03/G03 > A68/29E03/C10 (16.5-kDa OMP); A59/05F01/C09 $>$ A59/01E11/D11 (25-27-kDa OMP) and A68/ 15B06/C08 > A63/04D11/G01 (36-38-kDa OMP).

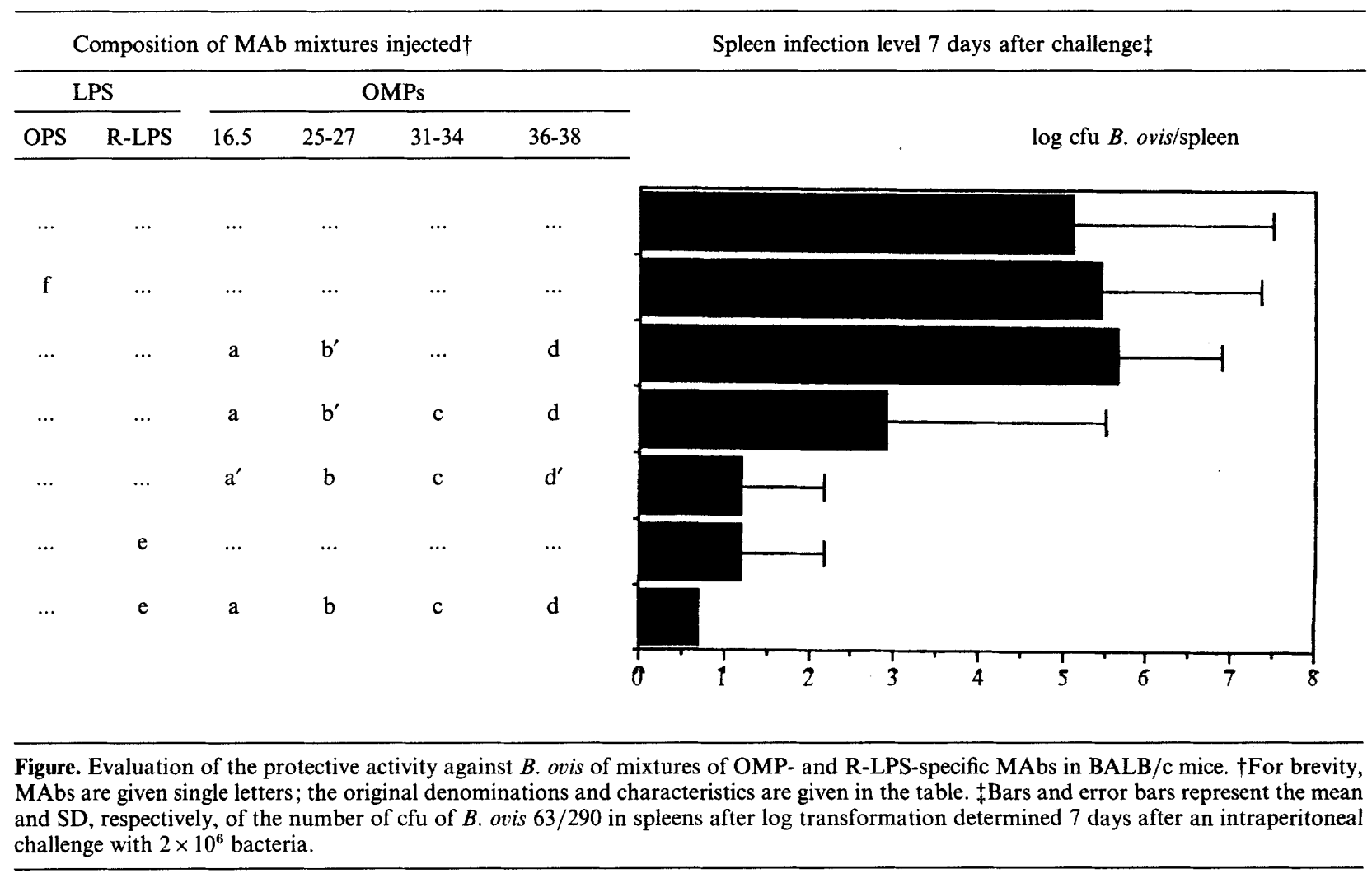


The highest binding activities were observed with anti31-34-kDa OMP and the anti-R-LPS MAbs.

A high number of viable Brucella organisms were found at necropsy in the spleens of non-immunised mice challenge-infected with $B$. ovis $63 / 290$ (figure). Furthermore, mice that had received MAb 04/F09, specific for the OPS of Brucella spp, showed no significant differences from the non-immunised group. Significant protection was not observed with the mixture of MAbs A76/08C03/G03 (16.5-kDa OMP), A59/05F01/C09 (25-27-kDa OMP) and A68/ $15 \mathrm{~B} 06 / \mathrm{C} 08(36-38 \mathrm{kDa})$. Addition of MAb A59/ $10 \mathrm{~F} 09 / \mathrm{G} 10$ (31-34-kDa OMP) to these MAbs resulted in a significant protection level $(\mathrm{p}<0.05)$. MAbs A68/29E03/C10, A59/01E11/D11 and A63/04D11/ G01 together with MAb A59/10F9/G10 gave the highest level of protection $(3.94 \log$ units, $\mathrm{p}<0.01)$. Anti-R-LPS MAb A68/03F03/D05 injected alone was very effective, inducing a protection level comparable with that obtained with the last mentioned combination of anti-OMP MAbs. When MAb A68/03F03/D05 was tested in association with the most protective mixture of anti-OMP MAbs (MAbs A68/29E03/C10, A59/01E11/D11, A5910F09/G10 and $A 63 / 04 \mathrm{D} 11 / \mathrm{G} 01$ ), the level of protection $(4.44 \mathrm{log}$ units) was even greater than that produced by the administration of the anti-OMP MAbs and anti-RLPS MAb separately.

\section{Discussion}

The results indicate that both OMP- and R-LPSspecific MAbs can confer protection against $B$. or is infection in $\mathrm{BALB} / \mathrm{c}$ mice. In this study, passive protection experiments with MAbs were used, an approach already used in the study of protective immunity against infections by naturally smooth $B$. abortus and $B$. melitensis strains. ${ }^{16,1823}$

Anti-OMP MAbs were selected on the basis of their binding on to whole B. ovis $63 / 290$ cells in ELISA. For in-vivo assessment of protective capacity, MAbs were tested in mixtures that included one MAb for each of the OMPs, grouping them according to their binding activity in ELISA. However, MAb binding was not correlated with the protective activity observed. Indeed, the mixture of MAbs A76/08C03/G03 (16.5kDa OMP), A59/05F01/C09 (25-27-kDa OMP) and A68/15B06/C08 (36-38 kDa), which bound better than MAbs A68/29E03/C10, A59/01E11/D11 and A63/04D11/G01 specific for the same OMPs, provided lower protection than the latter when tested together with MAb A59/10F09/G10 (31-34 kDa). The mixture of MAbs A76/08C03/G03 (16.5-kDa OMP), A59/05F01/C09 (25-27-kDa OMP) and A68/15B06/C08 (36-38-kDa OMP) gave no protection. Although the MAb specific for the $31-34-\mathrm{kDa}$ OMP was not tested individually, the increase in protection observed when it was included in other $\mathrm{MAb}$ mixtures suggested that this MAb would be active by itself. Thus, the differences in levels of protection observed could be attributed either to intrinsic activity of the MAbs or, alternatively, to detrimental interactions between MAbs, such as a blocking effect.

Differences in activity between mixtures of antiOMP MAbs would indicate that caution should be taken in the choice of OMPs constituting a vaccine against $B$. ovis. To date, conservation of antigenicity among $B$. ovis strains has been demonstrated only by testing immnoblots with polyclonal immune sera. ${ }^{13}$ If particular epitopes of OMPs behave differently, as the results of the present study would suggest, then the possibility of antigenic variability should also be considered. In previous studies, MAbs to brucella OMPs were ineffective ${ }^{16,17,22}$ or slightly protective ${ }^{16,17}$ against experimental infections with smooth brucella. In contrast, MAbs directed to the $\mathrm{A}, \mathrm{M}$ or common epitopes of the OPS were protective. ${ }^{18-20,22,23}$ However in B. ovis, a naturally rough Brucella species, OPS is lacking; thus, OMP epitopes are readily accessible to MAbs (R. A. Bowden, unpublished observations) which may in part explain the differences in protective activity observed.

The protection obtained with anti-R-LPS MAb A68/03F03/D05 suggests that R-LPS may be an interesting target for protective immunity to the naturally rough $B$. ovis. However, we have already shown that this $\mathrm{MAb}$ was ineffective in controlling smooth $B$. abortus infection in mice. ${ }^{21}$ This difference could be explained as being due to a lower accessibility of the MAb to R-LPS epitopes in smooth Brucella strains. ${ }^{21}$ On the other hand, B. ovis possesses wellexposed R-LPS epitopes, easily bound by MAbs. Others have claimed that R-LPS would not be an interesting candidate for a $B$. ovis vaccine because of its relatively poor immunogenicity in mice. ${ }^{12}$ Nevertheless, it has been shown previously in active immunisation studies that HS extract from which $\mathrm{R}$-LPS had been extensively depleted resulted in lower protective activity in rams than the crude, untreated HS, ${ }^{11}$ suggesting a protective role for R-LPS. The results presented here with a single anti-R-LPS MAb indicate that induction of antibodies to R-LPS would be valuable to control $B$. ovis infection. Therefore, the immunogenicity of $B$. ovis R-LPS should be studied further.

In mice, antibodies raised by immunisation with $B$. ovis ${ }^{12}$ or rough $B$. abortus $\mathrm{RB} 51^{24}$ have been shown to contribute to a greater extent than $T$ cells to the control of $B$. ovis infection. This study confirmed the protective activity of antibodies against $B$. ovis and identified OMPs and R-LPS as targets for protective MAbs. Experiments are under way to examine further whether single OMPs and other R-LPS MAbs could confer protection and to identify individually the OMPs involved in protection.

We thank J. M. Verger and M. Grayon for supplying the B. ovis reference strain 63/290. R.A.B. thanks INRA and Facultad de Ciencias Veterinarias, UNICEN, Tandil, Argentina for support. $\mathrm{AC}$. received a post-doctoral fellowship from the CEC. 


\section{References}

1. Blasco JM. Brucella ovis. In: Nielsen, $K$ and Duncan JR (eds) Animal brucellosis. Boca Raton: CRC Press, 1990: 351-378.

2. Bulgin MS. Epididymitis in rams and lambs. Vet Clin North Am Food Anim Pract 1990; 6: 683-690.

3. Blasco JM, Marín CM, Barberán M, Moriyón I, Díaz R. Immunization with Brucella melitensis Rev 1 against Brucella ovis infection of rams. Vet Microbiol 1987; 14: 381-392.

4. Afzal M, Brodie SJ, Tengerdy RP, Squire PG. Isolation and antigenic reactivity of Brucella ovis outer membrane proteins. J Clin Microbiol 1987; 25: 2132-2135.

5. Chin J, Turner B. Extraction of membrane antigens from Brucella ovis and an assessment of their serological activity by immunoblotting. J Gen Microbiol 1990; 136: 1615-1622.

6. Myers DM, Siniuk AA. Preliminary report on the development of a diffusion-in-gel method for the diagnosis of ram epididymitis. Appl Microbiol 1970; 19, 335-337.

7. Riezu Boj JI, Moriyón I, Blasco JM, Gamazo C, Díaz R. Antibody response to Brucella ovis outer membrane proteins in ovine brucellosis. Infect Immun 1990; 58: 489-494.

8. Suárez CE, Pacheco GA, Vigliocco AM. Characterization of Brucella ovis surface antigens. Vet Microbiol 1988; 18: 349-356.

9. Suárez CE, Pacheco GA, Vigliocco AM. Immunochemical studies of oligosaccharides obtained from the lipopolysaccharide of Brucella ovis. Vet Microbiol 1990; 22: 329-334.

10. Suárez CE, Pacheco GA, Vigliocco AM. Immunochemical studies on a Brucella ovis specific protein antigen. Vet Microbiol 1991; 27: 125-131.

11. Blasco JM, Gamazo C, Winter AJ et al. Evaluation of whole cell and subcellular vaccines against Brucella ovis in rams. Vet Immunol Immunopathol 1993; 37: 257-270.

12. Jiménez de Bagués MP, Elzer PH, Blasco JM, Marín CM, Gamazo C, Winter AJ. Protective immunity to Brucella ovis in BALB/c mice following recovery from primary infection or immunization with subcellular vaccines. Infect Immun 1994; 62: 632-638.

13. Gamazo C, Winter AJ, Moriyón I, Riezu-Boj JI, Blasco JM, Díaz R. Comparative analyses of proteins extracted by hot saline or released spontaneously into outer-membrane blebs from field strains of Brucella ovis and Brucella melitensis. Infect Immun 1989; 57: 1419-1426.
14. Alton GG, Jones LM, Angus RD, Verger JM. Techniques for the brucellosis laboratory. Institut National de la Recherche Agronomique, Paris, France, 1988.

15. Cloeckaert A, de Wergifosse P, Dubray G, Limet JN. Identification of seven surface-exposed Brucella outer membrane proteins by use of monoclonal antibodies: immunogold labeling for electron microscopy and enzyme-linked immunosorbent assay. Infect Immun 1990; 58: 3980-3987.

16. Cloeckaert A, Jacques I, Bosseray $\mathrm{N}$ et al. Protection conferred on mice by monoclonal antibodies directed against outermembrane-protein antigens of Brucella. $J$ Med Microbiol 1991; 34: 175-180.

17. Jacques I, Cloeckaert A, Limet JN Dubray G. Protection conferred on mice by combinations of monoclonal antibodies directed against outer-membrane proteins or smooth lipopolysaccharide of Brucella. J Med Microbiol 1992; 37: 100-103.

18. Cloeckaert A, Jacques I, de Wergifosse P, Dubray G, Limet JN. Protection against Brucella melitensis or Brucella abortus in mice with immunoglobulin G (IgG), IgA and IgM monoclonal antibodies specific for a common epitope shared by the Brucella $\mathrm{A}$ and $\mathrm{M}$ smooth lipopolysaccharides. Infect Immun 1992; 60: 312-315.

19. Limet JN, Plommet AM, Dubray G, Plommet M. Immunity conferred to mice by anti-LPS monoclonal antibodies in murine brucellosis. Ann Inst Pasteur/Immunol 1987; 138: 417-424.

20. Limet JN, Bosseray N, Garin-Bastuji B, Dubray G, Plommet $M$. Humoral immunity in mice mediated by monoclonal antibodies directed against the $\mathrm{A}$ and $\mathrm{M}$ antigens of Brucella. J Med Microbiol 1989; 30: 37-43.

21. Cloeckaert A, Jacques I, Bowden RA, Dubray G, Limet JN. Monoclonal antibodies to Brucella rough lipopolysaccharide: characterization and evaluation of their protective effect against B. abortus. Res Microbiol 1993; 144: 475-484.

22. Montaraz JA, Winter AJ, Hunter DM, Sowa BA, Wu AM, Adams LG. Protection against Brucella abortus in mice with O-polysaccharide-specific monoclonal antibodies. Infect Immun 1986; 51: 961-963.

23. Phillips M, Deyoe BL, Canning PC. Protection of mice against Brucella abortus infection by inoculation with monoclonal antibodies recognizing Brucella O-antigen. Am J Vet Res 1989; 50: 2158-2161.

24. Jiménez de Bagués MP, Elzer PH, Jones SM et al. Vaccination with Brucella abortus rough mutant RB51 protects BALB/c mice against virulent strains of Brucella abortus, Brucella melitensis, and Brucella ovis. Infect Immun 1994; 62: $4990-4996$. 